\title{
Pemodelan Survival pada Kejadian Demam Berdarah Dengue di Surabaya Timur dengan Pendekatan Bayesian
}

\author{
Ni Luh Putu Ika Candrawengi, Nur Iriawan dan Irhamah \\ Departemen Statistika, Institut Teknologi Sepuluh Nopember (ITS) \\ e-mail:nur_i@statistika.its.ac.id
}

\begin{abstract}
Abstrak-Salah satu penyakit yang paling sering dialami di Indonesia khususnya pada saat musim penghujan adalah penyakit Demam Berdarah Dengue (DBD). Penyakit ini disebabkan oleh virus dengue yang ditularkan oleh nyamuk Aedes aegypti betina. Untuk mengetahui laju kesembuhan pasien maka perlu diketahui faktor-faktor yang dapat mempengaruhinya. Salah satu metode yang dapat digunakan adalah analisis survival. Analisis survival merupakan analisis mengenai data yang diperoleh dari catatan waktu yang dicapai suatu objek sampai terjadinya event. Dalam penelitian ini event yang digunakan adalah waktu hingga sembuh (lama rawat inap) pasien. Analisis Bayesian memperlakukan semua parameter yang tidak diketahui sebagai variabel random dan memiliki distribusi. Dalam mengestimasi parameter digunakan pendekatan bayesian untuk mengatasi kasus jumlah data terbatas karena pada bayesian menggunakan estimasi dengan mempertimbangkan distribusi prior. Digunakan dua macam distribusi yang berbeda untuk memodelkan survival untuk kasus demam berdarah dengue. Distribusi yang digunakan adalah distribusi Generalized Gamma dan Weibull. Model yang terbaik yang ditunjukkan dengan nilai WAIC terkecil adalah model survival dengan menggunakan distribusi Weibull.
\end{abstract}

Kata Kunci-Analisis Survival , Bayesian, Demam Berdarah Dengue, Kesembuhan.

\section{PENDAHULUAN}

I NDONESIA merupakan negara iklim tropis yang memiliki dua musim yaitu musim penghujan dan musim kemarau. Musim penghujan dapat menimbulkan penyakit karena banyaknya virus, bakteri, jamur, dan parasit yang dapat berkembang akibat kelembaban yang tinggi. Salah satu virus yang cepat berkembang saat musim penghujan adalah virus dengue, apabila menjangkit manusia akan menimbulkan penyakit Demam Berdarah Dengue (DBD) yang kerap muncul di negara tropis seperti Indonesia [1].

Demam Berdarah Dengue (DBD) merupakan penyakit yang disebabkan oleh virus dengue dengan gejala demam 2-7 hari disertai dengan nyeri otot dan atau nyeri sendi, leukopenia, ruam, lifadenopati, trombositopenia, dan diatesis hemoragik . Penyakit DBD ditularkan melalui gigitan nyamuk Aedes aegypti. Menurut data WHO, Indonesia dilaporkan sebagai negara ke-2 dengan kasus DBD terbesar diantara 30 negara wilayah endemis. Kasus Demam Berdarah Dengue (DBD) yang terjadi di Indonesia pada tahun 2017 mengalami penurunan signifikan dari tahun 2016 yang mulanya terdapat 204171 kasus menjadi 68407 kasus. Provinsi Jawa Timur merupakan salah satu provinsi dengan kasus DBD tertinggi dengan jumlah kasus sebesar 7866 kasus. Pada tahun 2018 kasus DBD kembali meningkat dengan angka jumlah kasus sebanyak 9452 kasus. Kasus kematian akibat DBD yang terjadi di Indonesia pada tahun 2017 mengalami penurunan hampir tiga kali lipat. Pada tahun 2017 dan 2018 kasus kematian akibat DBD tertinggi terjadi di Provinsi Jawa Timur dengan banyak kematian 105 kematian [2]. Surabaya pada tahun 2018 mengalami penurunan kasus penyakit DBD. Walaupun terjadi penurunan kasus demam berdarah tetapi masih ada beberapa kecamatan di Surabaya yang memiliki angka kasus Demam Berdarah tinggi khususnya untuk wilayah Surabaya Timur.

Pada suatu data yang memiliki variabel respon berupa waktu terjadinya suatu event diperlukan suatu analisis yaitu analisis survival Analisis survival adalah analisis mengenai data yang diperoleh dari catatan waktu yang dicapai suatu objek sampai terjadinya event. Untuk mengetahui faktor-faktor yang berpengaruh terhadap laju kesembuhan pasien DBD, maka perlu dilakukan penelitian secara statistik untuk dapat mengurangi kasus kematian yang disebabkan oleh DBD. Hal ini dilakukan untuk mengetahui peluang pasien DBD untuk bertahan hidup, serta dalam metode penyembuhan beberapa pasien dapat bertahan dan seberapa besar kegagalan dari metode tersebut

Berdasarkan uraian tersebut, maka perlu dilakukan penelitian untuk mengkaji waktu kesembuhan pasien penyakit DBD berdasarkan faktor demografi, geografi, dan faktor host dari pasien DBD. Penelitian ini akan mengidentifikasi pola data pada waktu lama rawat inap untuk mengetahui model yang tepat untuk digunakan. Selanjutnya, dilakukan pemodelan survival berdasarkan faktor-faktor yang mempengaruhi laju kesembuhan pasien DBD yang diestimasi dengan Bayesian.

\section{TINJAUAN PUSTAKA}

\section{A. Pengujian Kesesuaian Distribusi}

Pemeriksaan kesesuaian antara pola distribusi data observasi dengan pola distribusi yang dipilih merupakan salah satu tujuan untuk melalukan pengujian kesesuaian distribusi. Beberapa metode yang sering digunakan untuk pengujian kesesuaian distribusi data, diantaranya yaitu Anderson Darling, Kolmogorov-Smirnov, dan Chi-square. Pada penelitian ini pengujian kesesuaian distribusi yang digunakan adalah menggunakan uji Kolmogorov-Smirnov (KS). Uji KolmogorovSmirnov (KS) merupakan pengujian yang didasarkan pada pendekatan distribusi kumulatif atau Cumulative Density Function (CDF). Selain itu, uji Kolmogorov-Smirnov (KS) 
merupakan uji yang paling sering digunakan dalam pengujin distribusi[3]. Berikut merupakan Hipotesis uji Kolmogorov Smirnov:

$\mathrm{H}_{0}: F_{n}(x)=F_{0}(x)$ atau data mengikuti pola distribusi tertentu

$\mathrm{H}_{1} \quad: F_{n}(x) \neq F_{0}(x)$ atau data tidak mengikuti pola distribusi tertentu

Nilai statistik uji Kolmogorov-Smirnov adalah sebagai berikut.

$$
D=\max \left|F_{n}(x)-F_{0}(x)\right|
$$

dengan,

$F_{0}(x)$ : fungsi distribusi yang dihipotesiskan,

$F_{n}(x)$ : fungsi distribusi data secara empiris.

Daerah penolakan untuk hipotesis ini adalah jika nilai uji Dlebih besar dari tabel critical value Kolmogorov-Smirnov. Selain menggunakan statistik uji seperti pada Persamaan (1), pengujian KS juga dapat dilihat dari $p$-value. Tolak $\mathrm{H}_{0}$ apabila $p$-value kurang dari taraf signifikan $\alpha$ yang digunakan.

\section{B. Analisis Survival}

Analisis survival merupakan salah satu metode dalam statistika yang digunakan untuk menganalisis data yang memiliki variabel respon berupa waktu sampai terjadinya suatu event. Event merupakan suatu peristiwa ekstrim yang mungkin terjadi pada individu seperti kesembuhan, kekambuhan, ataupun kematian setelah dilakukan suatu proses treatment. Respon dari analisis survival didefinisikan sebagai range waktu dari awal penelitian hingga suatu event terjadi atau sampai penelitian berakhir [4]. Elemen-elemen yang harus diperhatikan dalam menentukan waktu survival adalah sebagai berikut :

1. Time origin/starting point atau merupakan titik awal, misalnya wakti awal dimulainya suatu treatment.

2. Failure time yaitu waktu berakhirnya failure event, misalnya tanggal keluar rumah sakit atau tanggal kematian

3. Measurement scale of time atau skala pengukuran waktu, misalnya hari atau bulan.

\section{Fungsi Survival}

Fungsi survival merupakan probabilitas bahwa suatu individu tidak mengalami kejadian lebih dari waktu $t$. Fungsi survival $S(t)$ dapat dinyatakan sebagai peluang seorang individu untuk bertahan lebih lama dari suatu waktu $t$ [4]. Berikut merupakan persamaan untuk fungsi survival.

$$
S(t)=P(T>t)=1-P(T \leq t)=1-F(t)
$$

Fungsi hazzard merupakan laju kegagalan (failure) sesaat ketika mengalami suatu event pada waktu ke- $t$. Berbeda dengan fungsi survival yang fokus pada keberhasilan, fungsi hazard fokus pada kegagalan ketika kejadian berlangsung. Fungsi hazard dapat dinyatakan dalam persamaan berikut.

$$
h(t)=\frac{f(t)}{S(t)}
$$

Hubungan antara $H(t)$ atau fungsi kumulatif hazard dengan fungsi survival $S(t)$ adalah sebagai berikut :

$$
H(t)=-\ln S(t)
$$

dengan :

$t \quad$ : Waktu yang diamati,

$T \quad$ : Waktu survival seorang individu,

$F(t) \quad$ : Fungsi distribusi kumulatif (CDF) dari distribusi data,

$f(t) \quad$ : Fungsi kepadatan peluang (PDF),

$S(t) \quad$ : Fungsi survival,

$h(t) \quad$ : Fungsi hazard proporsional,

$H(t) \quad$ : Fungsi kumulatif hazard.

\section{Asumsi Proporsional Hazard}

Pengujian asumsi proportional hazard juga dapat dilakukan dengan menggunakan statistik uji goodness of fit. Adapun langkah-langkah untuk pengujian asumsi dengan uji goodness of fit adalah sebagai berikut.

1. Mendapatkan residual schoenfeld untuk setiap variabel prediktor dari model cox.

2. Membuat variabel rank waktu survival dari urutan kecil ke besar

3. Menghitung korelasi antara residual schoenfeld dan rank dari waktu survival menggunakan rumus pada Persamaan

$$
r_{R T, P R_{i}}=\frac{\sum_{j=1}^{n}\left(P R_{i j}-P \bar{R}\right)\left(R T_{j}-R \bar{T}\right)}{\sqrt{\sum_{j=1}^{n}\left(P R_{i j}-P \bar{R}\right)^{2}} \sqrt{\sum_{j=1}^{n}\left(R T_{j}-R \bar{T}\right)^{2}}}
$$

Keterangan :

$P R_{i j}$ : residual schoenfeld untuk variabel prediktor ke-i individu yang mengalami event pada $t_{(j)}$.

$R T_{j}$ : rank waktu survival yang diurutkan dari kecil ke besar pada $t_{(j)}$.

4. Melakukan pengujian korelasi antara residual schoenfeld dan rank waktu survival dengan hipotesis sebagai berikut.

$\mathrm{H}_{0}: \rho=0$

$\mathrm{H}_{1}: \rho \neq 0$

Statistik uji yang digunakan adalah sebagai berikut,

$$
t_{\text {hit }}=\frac{r_{R T, P R_{i}} \sqrt{n-2}}{\sqrt{1-r_{R T, P R_{i}}^{2}}}
$$

Tolak $\mathrm{H}_{0}$ jika $\left|t_{h i t}\right|>t_{\frac{\alpha}{2}, n-2}$ atau nilai $p$-value kurang dari taraf kesalahan $(\alpha)$ yang digunakan. Asumsi propotional hazard terpenuhi jika uji korelasi antara residual schoenfeld dan rank waktu survival tidak signifikan atau gagal tolak $\mathrm{H}_{0}$ [4].

Perhitungan numerik dengan statistik uji global Grambsh and Thernau yang berdasarkan residual schoenfeld pada regresi cox dengan hipotesis sebagai berikut :

$H_{0}$ : Asumsi proporsional hazard terpenuhi

$H_{1}$ : Asumsi proporsional hazard tidak terpenuhi

Persamaan (7) merupakan statistik uji global variabel ke- $p$ $\left(G_{p}\right)$ :

$$
G_{p}=\frac{\sum_{i=1}^{M} \sum_{j=1}^{N i}\left(\delta_{i j} h\left(t_{i j}\right)-\bar{h}\right) r_{s i j}}{I_{p} \sum_{i=1}^{M} \sum_{j=1}^{N i}\left(\delta_{i j} h\left(t_{i j}\right)-\bar{h}\right)} \sim \chi_{(1)}^{2},
$$


dengan :

$$
r_{s_{p i j}}=\delta_{i j}\left\{x_{i j}-\bar{\alpha}_{p i j}\right\}
$$

dimana,

$$
\bar{\alpha}_{p i j}=\frac{\sum_{I \in R_{f}} x_{p i j} \exp \left(\boldsymbol{\beta} x_{I}\right)}{\sum_{I \in R_{f}} \exp \left(\boldsymbol{\beta} x_{I}\right)}
$$

$\delta_{i j}$ menunjukkan status kejadian (tersensor (0) dan tidak tersensor (1)), $I_{p}$ merupakan elemen information matrix variabel ke- $p, r_{s_{p i j}}$ merupakan nilai residual Schoenfeld dan kesimpulan gagal tolak $H_{0}$, jika nilai $G_{p}<\chi_{(1)}^{2}$ atau jika nilai $P$-value $>\alpha[5]$.

\section{E. Model Proportional Hazard}

Model proportional hazard atau cox proportional hazard (Cox $\mathrm{PH})$ adalah suatu pemodelan matematis yang digunakan untuk menganalisis data survival. Pada model cox PH mampu mengestimasi koefisien regresi, hazard ratio, dan kurva survival. Cox PH merupakan model yang robust karena hasil dari model Cox PH mendekati aproksimasi hasil dari model parametrik [4]. Model cox PH merupakan model semiparametrik karena model Cox PH tidak memerlukan informasi tentang distribusi yang mendasari waktu survival dan estimasi parameter regresi dari model cox $\mathrm{PH}$ tanpa harus menentukan baseline hazard. Adapun persamaan model Cox PH dapat ditulis seperti Persamaan 21[4].

$$
\begin{gathered}
h(t, X)=h_{0}(t) e^{\Sigma_{i=1}^{p} \beta_{i} X_{i}} \\
h(t, X)=h_{0}(t) \exp \left(\beta_{1} x_{i}+\beta_{2} x_{2}+\ldots+\beta_{p} x_{p}\right)
\end{gathered}
$$

dimana,

$\left(X_{1}, X_{2}, \ldots, X_{p}\right) \quad$ : Vektor yang berisi $\mathrm{p}$ variabel prediktor

$h_{0}(t) \quad:$ Baseline hazard yang menggambarkan model hazard ketika semua variabel prediktornya bernilai nol

$\left(\beta_{1}, \beta_{2}, \ldots, \beta_{p}\right) \quad$ : Vektor pada parameter regresi

\section{F. Analisis Bayesian}

Estimasi parameter suatu model dapat digolongkan ke dalam dua kelompok yaitu data pengamatan saat ini yang bersifat sesaat selama studi dan data yang bersifat long memory histogram yang dikumpulkan di masa lampau [6]. Analisis Bayesian memperlakukan semua parameter yang tidak diketahui sebagai variabel random dan memiliki distribusi, sehingga analisis Bayesian berbeda dengan teori statsitika klasik [7]. Dasar dari teorema Bayesian adalah distribusi posterior yang merupakan perkalian antara distribusi prior dengan data obserbasi penyusun fungsi likelihood [8].

Pada Penelitian ini, jika diketahui $t$ adalah sebuah variabel random dengan fungsi densitas $f(\boldsymbol{t} \mid \boldsymbol{\theta})$ dengan mengikuti pola distribusi tertentu. $\boldsymbol{\theta}$ merupakan vektor parameter dengan $\boldsymbol{\theta}=$ $\left(\beta_{1}, \beta_{2}, \ldots, \beta_{p}, \alpha, \gamma\right)$ yang memiliki ukuran sebanyak parameter yang digunakan, dalam penelitian ini parameter ukuran parameter yaitup +1 , sedangkan $t$ merupakan vektor sampel yang memiliki ukuran $\mathrm{n}$ dengan distribusi identik dan independent. Joint posterior dari $\boldsymbol{\theta}$ dan $\boldsymbol{t}$ dapat dituliskan dalam bentuk persamaan berikut.

$$
f(\boldsymbol{\theta} \mid t)=\frac{f(\boldsymbol{t} \mid \boldsymbol{\theta}) f(\boldsymbol{\theta})}{f(t)}
$$

didapatkan conditional distribution yang dituliskan dalam persamaan berikut.

$$
f(\boldsymbol{\theta} \mid t) \propto f(\boldsymbol{t} \mid \boldsymbol{\theta}) f(\boldsymbol{\theta}),
$$

dengan :

$f(\boldsymbol{t} \mid \boldsymbol{\theta})$ : fungsi likelihood,

$\boldsymbol{f}(\boldsymbol{\theta}) \quad$ : joint distribution $\boldsymbol{\theta}$ sebagai $f(\boldsymbol{\theta})=$

$f\left(\beta_{1}\right) . f\left(\beta_{2}\right), \ldots, f\left(\beta_{p}\right) . f(\alpha) . f(\gamma)$,

$f(t) \quad$ : total probabilitas bayes yang berfungsi sebagai konstanta penormal fungsi distribusi densitas.

Penentuan distribusi prior sangat penting karena mempengaruhi bentuk distribusi posterior yang akan digunakan untuk pengambilan keputusan. Jika tidak terdapat informasi prior dapat digunakan non-informative prior dengan memberikan nilai yang tidak akan mempengaruhi distribusi posterior. Berikut ini merupakan macam-macam distribusi prior, antara lain :

a. Informative dan noninformative prior merupakan penentuan prior yang didasarkan pada ada atau tidaknya informasi yang diperoleh dari penelitian sebelumnya mengenai pola distribusi data.

b. Conjugate dan nonconjugate prior merupakan penentuan prior yang didasarkan dari pola likelihood data.

c. Proper dan improper prior merupakan penentuan prior tergantung pada pemberian pembobotan/densitas di setiap titik, apakah terdistribusi secara uniform atau tidak

d. Pseudo prior merupakan penentuan prior dengan nilai yang pemberian nilainya didasarkan dan disetarakan dengan hasil elaborasi cara frequentist.

Distribusi posterior merupakan distribusi peluang yang berisi informasi mengenai parameter $\boldsymbol{\theta}$ atau dapat dinyatakan dalam $f(\boldsymbol{\theta} \mid t)$. Distribusi posterior merupakan gabungan antara informasi prior dan data observasi (fungsi likelihood). Markov Chain Monte Carlo (MCMC) merupakan suatu pendekatan yang dapat digunakan untuk memecahkan masalah dalam hal pembaharuan parameter dari sampel melalui distribusi posterior. Markov Chain Monte Carlo (MCMC) dapat digunakan untuk membentuk model yang sangat kompleks, berdimensi tinggi atau memiliki sifat data yang berkorelasi tinggi. Untuk mendapatkan distribusi prior yang stasioner, MCMC memiliki ide dasar dengan membangkitkan sebuah Markov Chain dengan simulasi Monte Carlo yang beriterasi. Salah satu algoritma dari MCMC yang mencakup iteratif sampling dari setiap distribusi bersyarat adalah Gibbs. Algoritma Gibbs sampling dapat digunakan walaupun data memiliki distribusi yang rumit dan tidak diberitahu secara eksplisit asalkan distribusi kondisional bersyarat univariat [9]. Diberikan $\boldsymbol{\theta}=\left(\beta_{1}, \beta_{2}, \ldots, \beta_{p}, \alpha, \gamma\right)$, dimana bentuk distribusi full conditional yang digunakan untuk masing-masing parameter adalah: sampling. Algoritma gibbs sampling digunakan untuk mengambil sampel dari distribusi kompleks berdimensi tinggi.

$$
\begin{gathered}
p\left(\alpha \mid \boldsymbol{x}, \beta_{2}, \ldots, \beta_{p}, \gamma\right), p\left(\gamma \mid \boldsymbol{x}, \beta_{2}, \ldots, \beta_{p}, \alpha\right), \\
\left.p\left(\beta_{1} \mid \boldsymbol{x}, \beta_{2}, \ldots, \beta_{p}, \alpha, \gamma\right), \ldots, p\left(\beta_{p} \mid \boldsymbol{x}, \beta_{1}, \ldots, \beta_{p-1}, \alpha, \gamma\right)\right)
\end{gathered}
$$


atau dapat ditulis dengan $\boldsymbol{\theta}^{(1)}, \boldsymbol{\theta}^{(2)}, \ldots, \boldsymbol{\theta}^{(p)}$. Berikut ini merupakan langkah-langkah dari algoritma gibss samppling :

1. Mengambil nilai $m=0$ dan menentukan nilai inisiasi (initial value) dari $\boldsymbol{\theta}^{(0)}=\left(\beta_{1}^{(0)}, \beta_{2}^{(0)}, \ldots, \beta_{p}^{(0)}, \alpha^{(0)}, \gamma^{(0)}\right)$.

2. Membangkitkan tiap komponen dari $\boldsymbol{\theta}^{(m+1)}=$ $\left(\beta_{1}^{(m+1)}, \beta_{2}^{(m+1)}, \ldots, \beta_{p}^{(m+1)}, \alpha^{(m+1)}, \gamma^{(m+1)}\right)$

dimana,

Nilai $\alpha^{(m+1)}$ berasal dari $p\left(\beta_{1} \mid \boldsymbol{X}, \beta_{1}^{(m)}, \ldots, \beta_{p}^{(m)}, \gamma^{(m)}\right)$

Nilai berasal dari $p\left(\beta_{1} \mid \boldsymbol{X}, \beta_{1}^{(m)}, \ldots, \beta_{p}^{(m)}, \alpha^{(m+1)}\right)$

Nilai berasal dari $p\left(\beta_{1} \mid \boldsymbol{X}, \beta_{2}^{(m)}, \ldots, \beta_{p}^{(m)}, \alpha^{(m+1)}, \gamma^{(m+1)}\right)$

Nilai $\beta_{2}^{(m+1)}$ berasal dari $p\left(\beta_{2} \mid \boldsymbol{X}, \beta_{1}^{(m+1)}, \ldots, \beta_{p}^{(m)}, \alpha^{(m+1)}\right.$, $\left.\gamma^{(m+1)}\right)$

Nilai $\beta_{p}^{(m+1)}$ berasal dari $p\left(\beta_{p} \mid \boldsymbol{X}, \beta_{1}^{(m+1)}, \ldots, \beta_{p-1}^{(m+1)}\right.$, $\left.\alpha^{(m+1)}, \gamma^{(m+1)}\right)$

3. Melakukan monitoring terhadap kekonvergenan algoritma. Apabila belum konvergen, maka dibangkitkan lebih banyak observasi dengan mengambil nilai $m_{1}=$ $m+1, m_{2}=m+1, \ldots, m_{k}=m+k a$ dan diulangi Langkah 1 dan Langkah 2.

4. Membuang $b$ observasi pertama (burn in period). Hal ini dilakukan untuk menghindari pengaruh initial value.

5. Anggap $\boldsymbol{\theta}^{(1)}, \boldsymbol{\theta}^{(2)}, \ldots, \boldsymbol{\theta}^{(p)}$ dan sebanyak b observasi pertama sudah dibuang dan diperoleh sampel $\boldsymbol{\theta}^{(b+1)}, \boldsymbol{\theta}^{(b+2)}, \ldots, \boldsymbol{\theta}^{(k)}$ untuk analisis posterior,

6. Membuat plot distribusi posterior.

7. Mendapatkan mean, median, standar deviasi, kuantil, dan MC error dari posterior.

\section{G. Watanabe Akaike Information Criterion (WAIC)}

Watanabe Akaike Information Criterion (WAIC) atau yang biasa dikenal dengan Widely Applicable Information Criterion adalah salah satu pendekatan bayesian untuk mengestimasi ekspektasi out-of-sample. Metode ini dimulai dengan menghitung log dari fungsi densitas posterior dan menambahkan koreksi untuk jumlah parameter efektif yang disesuaikan untuk overfitting. Dibandingkan dengan DIC dan AIC, WAIC memiliki sifat yang berada diatas rata-rata diatas distribusi posterior dibandingkan dalam satu estimasi titik. Hal ini sangat relevan digunakan dalam prediksi karena WAIC mengevaluasi prediksi yang sebenarnya digunakan untuk data baru dalam konteks Bayesian [10]. Rumus untuk menghitung WAIC dapat dilihat pada Persamaan (14).

$$
W A I C=\operatorname{lppd}-p W A I C,
$$

dengan,

$$
p W A I C=\sum_{i=1}^{n} \operatorname{var}_{\text {post } \left.\log p\left(y_{i} \mid \theta\right)\right)}
$$

\section{H. Demam Berdarah Dengue (DBD)}

Demam Berdarah Dengue (DBD) adalah penyakit menular yang disebabkan oleh virus dengue dan ditularkan oleh nyamuk Aedes aegypti. Biasanya, penyakit demam berdarah ini ditandai dengan adanaya demam mendadak selama 2-7 hari, lemah/lesu, nyeri ulu hati, nyeru persendian, dan dapat disertai dengan tanda pendarahan dikulit berupa bintik-bintik. Jika penyakit
Tabel 1.

\begin{tabular}{|c|c|c|}
\hline Variabel & Nama Variabel & Skala \\
\hline $\mathrm{t}$ & Lama rawat inap pasien & Rasio \\
\hline t.cen & data tersensor & Nominal \\
\hline \multirow[t]{3}{*}{$\mathrm{X}_{1}$} & Jenis Kelamin Pasien & Nominal \\
\hline & $0:$ Perempuan & \\
\hline & 1 : Laki-laki & \\
\hline $\mathrm{X}_{2}$ & Usia pasien saat dirawat & Rasio \\
\hline \multirow[t]{6}{*}{$\mathrm{X}_{3}$} & Pendidikan terakhir pasien & Ordinal \\
\hline & $1: \mathrm{SD}$ & \\
\hline & $2:$ SMP & \\
\hline & 3: SMA & \\
\hline & $4:$ S1/D3 & \\
\hline & 5 : Lain-lain & \\
\hline \multirow[t]{6}{*}{$\mathrm{X}_{4}$} & Pekerjaan pasien : & Nominal \\
\hline & 1: Ibu Rumah Tangga & \\
\hline & 2: Pegawai Swasta & \\
\hline & 3: Pegawai Negeri & \\
\hline & 4: Tidak Bekerja & \\
\hline & 5: Lain-lain & \\
\hline \multirow[t]{5}{*}{$\mathrm{X}_{5}$} & Tingkatan/fase DBD yang & Ordinal \\
\hline & $\begin{array}{l}\text { diidap : } \\
\text { 1: I }\end{array}$ & \\
\hline & $2:$ II & \\
\hline & 3: III & \\
\hline & 1. IV & \\
\hline $\mathrm{X}_{6}$ & $\begin{array}{l}\text { Lama demam sebelum } \\
\text { masuk ke RS }\end{array}$ & Rasio \\
\hline $\mathrm{X}_{7}$ & $\begin{array}{l}\text { Banyaknya denyut nadi per } \\
\text { menit }\end{array}$ & Rasio \\
\hline $\mathrm{X}_{8}$ & Frekuensi pernafasan pasien & Rasio \\
\hline $\mathrm{X}_{9}$ & $\begin{array}{l}\text { Suhu badan pasien saat } \\
\text { pertama kali datang ke } \\
\text { rumah sakit }\end{array}$ & Rasio \\
\hline $\mathrm{X}_{10}$ & Kadar Hemoglobin Pasien & Rasio \\
\hline $\mathrm{X}_{11}$ & Kadar Hematokrit Pasien & Rasio \\
\hline $\mathrm{X}_{12}$ & Kadar sel darah putih pasien & Rasio \\
\hline $\mathrm{X}_{13}$ & $\begin{array}{l}\text { Kadar trombosit dalam } \\
\text { darah }\end{array}$ & Rasio \\
\hline
\end{tabular}

Variabel Penelitian

demam berdarah sudah sangat parah maka dapat disertai dengan mimisan, muntah darah, shock, bahkan dapat menimbulkan kematian. Tiga faktor penting yang memegang peranan pada penularan infeksi virus dengue yaitu manusia, virus, dan vektor perantara. Virus dengue ditularkan kepada manusia melalui gigitan nyamuk Aedes aegypti betina. Tidak semua orang yang didalam tubuhnya terdapat virus dengue akan sakit demam berdarah dengue. Beberapa akan mengalami demam ringan dan sembuh dengan sendirinya atau bahkan ada yang sama sekali tanpa gejala sakit.

\section{METODOLOGI PENELITIAN}

\section{A. Sumber Data}

Pada penelitian ini sumber data yang akan digunakan merupakan data sekunder yang diperoleh dari data rekam medis pasien rawat inap DBD di RSUD Dr. Soetomo Surabaya, waktu rekam medis dimulai dari tahun 2016 sampai 2019. Waktu penelitian adalah 1 Januari 2016 sampai dengan 31 Desember 2019.

\section{B. Variabel Penelitian}

Variabel-variabel yang digunakan dalam penelitian ini terdapat pada Tabel 1. 
Tabel 2.

Hasil Uji Proporsional Hazard

\begin{tabular}{|c|c|c|c|}
\hline Variabel & & rho & P-value \\
\hline Jenis Kelamin ( & & 0,05481 & 0,8374 \\
\hline Usia Pasien & & 0,41291 & 0,1397 \\
\hline $\begin{array}{l}\text { Pendidikan } \\
\text { (S1/D3) }\end{array}$ & Terakhir & $-0,2339-$ & 0,2671 \\
\hline $\begin{array}{l}\text { Pendidikan } \\
\text { (SMA) }\end{array}$ & Terakhir & $-0,20646$ & 0,3335 \\
\hline $\begin{array}{l}\text { Pekerjaan } \\
\text { Negeri }\end{array}$ & Pegawai & 0,09771 & 0,6676 \\
\hline $\begin{array}{l}\text { Pekerjaan } \\
\text { Swasta) }\end{array}$ & (Pegawai & $-0,11479$ & 0,6045 \\
\hline $\begin{array}{l}\text { Pekerjaan } \\
\text { Bekerja) }\end{array}$ & (Tidak & $-0,32063$ & 0,1018 \\
\hline $\begin{array}{l}\text { Lama demam } \\
\text { masuk RS }\end{array}$ & sebelum & 0,33498 & 0,0936 \\
\hline Fase DBD (II) & & $-0,20733$ & 0,3648 \\
\hline Fase DBD (III) & & $-0,01608$ & 0,9337 \\
\hline Denyut Nadi & & $-0,24943$ & 0,1697 \\
\hline Pernafasan & & 0,10119 & 0,6304 \\
\hline Suhu & & $-0,13837$ & 0,5282 \\
\hline HGB & & $-0,00966$ & 0,9645 \\
\hline HCT & & 0,16331 & 0,3972 \\
\hline WBC & & $-0,24273$ & 0,2864 \\
\hline PLT & & $-0,31504$ & 0,0627 \\
\hline GLOBAL & & NA & 0,8076 \\
\hline
\end{tabular}

\section{Langkah Analisis}

Langkah-langkah analisis dalam penelitian ini adalah :

1. Melakukan pengujian distribusi waktu rawat inap.

2. Melakukan pengujian asumsi pemodelan proporsional hazard.

3. Proses estimasi parameter untuk distribusi dari variabel respon lama rawat inap dengan menggunakan MCMC dan gibbs sampler.

4. Menentukan model survival spasial pada kejadian DBD di Surabaya Timur berdasarkan faktor-faktor yang mempengaruhi laju kesembuhan pasien menggunakan program OpenBUGS. Langkah-langkahnya dapat dijelaskan sebagai berikut.

i. Menentukan distribusi prior yang digunakan berdasarkan informasi dari data

ii. Menentukan joint posterior model survival

iii. Menentukan full conditional untuk setiap parameter

iv. Melakukan inisiasi untuk parameter awal

v. Menghitung nilai fungsi hazard dan survival pasien DBD berdasarkan posterior summaries yang diperoleh

5. Interpretasi model survival sehingga diperoleh faktorfaktor yang berpengaruh terhadap laju kesembuhan pasien DBD.

6. Menarik kesimpulan dan saran.

\section{ANALISIS DAN PEMBAHASAN}

\section{A. Pendugaan Distribusi Lama Rawat Inap (Waktu Survival) Pasien DBD}

Pendugaan distribusi dilakukan terhadap waktu survival $(t)$ yaitu lama rawat inap pasien DBD Surabaya Timur di RSUD Dr. Soetomo. Oleh sebab itu, dalam pengujian kesesuaian distribusi digunakan asumsi awal yaitu data dari lama rawat
Tabel 3 .

Uji Distribusi Waktu Survival

\begin{tabular}{llll}
\hline \hline Distribusi & Statistik Uji & Nilai Kritis & \multicolumn{2}{l}{ Keputusan } \\
\hline $\begin{array}{l}\text { Generalized } \\
\text { Gamma }\end{array}$ & 0,13276 & 0,28724 & Gagal tolak \\
Weibull & 0,15079 & 0,28724 & H0 \\
& & Gagal tolak & H0 \\
\hline \hline
\end{tabular}

inap pasien DBD berdistribusi Generalized Gamma 3P/Weibul 2P.

Hasil uji kesesuaian distribusi pada Tabel 2 menunjukkan bahwa waktu lama rawat inap (waktu survival) berdistribusi Generalized Gamma dan Weibull. Hal ini disebabkan karena nilai statistik uji Kolmogorov-Smirnov dari data lama rawat inap pasien DBD lebih kecil dibandingkan dengan nilai kritis yang ditetapkan sebesar 0,28274. Selain itu, lama waktu rawat inap pasien (waktu survival) selalu memiliki nilai yang cenderung positif sehingga distribusi yang sesuai yaitu Generalized Gamma dan distribusi Weibull.

\section{B. Asumsi Proportional Hazard}

Uji global Grambsch and Thernau juga digunakan dalam penelitian ini. Pengujian ini menggunakan hipotesis serta statistik uji sesuai dengan Persamaan (5). Tabel 3 Merupakan hasil uji Schoenfeld residual.

Hasil pengujian proprosional hazard dengan menggunakan korelasi antara residual Schoenfeld dengan waktu survival yang ditunjukkan dengan rho menunjukkan untuk seluruh variabel kategorik yang digunakan dalam penelitian ini memiliki nilai $P$ yang lebih dari taraf signifikansi sebesar 0,05. Sehingga, untuk seluruh variabel kategorik tidak signifikan sehingga gagal menolak hipotesis untuk asumsi proporsional hazard. Hasil Uji Global untuk menguji asumsi proporsional hazard untuk keseluruhan model secara simultan menunjukkan nilai $P$ sebesar 0,8076 yang lebih dari taraf signifikansi. Dari hasil uji Global dapat disimpulkan bahwa asumsi proporsional hazard terpenuhi pada model ini

\section{Penentuan Prior}

Pada penelitian ini digunakan dua macam distribusi untuk lama inap (waktu survival) pasien DBD yaitu distribusi Weibull 2 Parameter dan Generalized Gamma 3 parameter. Fungsi kepadatan peluang (PDF) untuk distribusi Weibull 2 parameter adalah sebagai berikut, $f(t \mid \gamma, \mu)=\mu \gamma t^{\gamma-1} \exp \left(-\mu t^{\gamma}\right)$.

Kemudian fungsi hazard untuk distribusi Weibull adalah sebagai berikut,

$h(t)=\gamma t^{\gamma-1} \exp \left(\beta_{1} x_{1}+\beta_{2} x_{x}+\ldots+\beta_{p} x_{p}\right)$,

sebelum melakukan estimasi terhadap parameter $\gamma$ dan untuk $\beta$, maka terlebih dahulu menentukan distribusi priornya sebagai berikut,

$$
\begin{aligned}
& \gamma \sim \operatorname{Gamma}(a, b), \\
& \beta_{i} \sim \operatorname{Normal}(m, \text { tau }) .
\end{aligned}
$$

Untuk distribusi Generalized Gamma diketahui fungsi kepadatan peluangnya adalah sebagai berikut,

$$
f(t \mid \gamma, \alpha, \beta)=\frac{\beta}{\Gamma(\alpha)} \frac{t^{\beta \alpha-1}}{\gamma^{\beta \alpha}} \exp \left(-\left(\frac{t}{\gamma}\right)^{\beta}\right),
$$


Tabel 4.

Nilai WAIC Masing-masing Model Survival

\begin{tabular}{lc}
\hline \hline \multicolumn{1}{c}{ Model } & WAIC \\
\hline Model Survival distribusi Generalized Gamma & 147,1 \\
Model survival distribusi Weibull & 93,01 \\
\hline \hline
\end{tabular}

dengan model hazard,

$$
h(t)=h_{0}(t) \exp \left(\beta_{1} x_{1}+\beta_{2} x_{x}+\ldots+\beta_{p} x_{p}\right) .
$$

Dimana $h_{0}(t)$ dari distribusi Generalized Gamma merupakan bentuk integral rumit yang memuat parameter $\alpha$ dan $\gamma$. Sebelum melakukan estimasi terhadap parameter $\alpha, \theta$ dan untuk $\beta$, maka terlebih dahulu menentukan distribusi priornya sebagai berikut,

$$
\begin{aligned}
& \alpha \sim \operatorname{Gamma}(a, b), \\
& \gamma \sim \operatorname{Gamma}(a, b), \\
& \beta_{i} \sim \operatorname{Normal}(m, \text { tau }),
\end{aligned}
$$

dimana penentuan distribusi prior tersebut dilakukan berdasarkan gabungan antara prior informatif dan pseudo prior.

\section{Faktor-faktor yang Signifikan Mempengaruhi Laju Kesembuhan Pasien DBD}

1) Faktor yang Signifikan Mempengaruhi Laju Kesembuhan Pasien DBD dengan Distribusi Weibull

Faktor-faktor yang dianggap signifikan untuk mempengaruhi laju kesembuhan pasien DBD di RSUD Dr. Soetomo adalah jika nilai dari credible interval 2,5\% hingga $97,5 \%$ tidak memuat nilai 0 . Tidak semua variabel mempengaruhi laju kesembuhan pasien DBD di RSUD Dr. Soetomo. Variabel yang berpengaruh terhadap kesembuhan pasien DBD adalah variabel jenis kelamin, pendidikan terakhir pasien untuk kategori S1/D3, pekerjaan pasien untuk kategori pegawai negeri dan lain-lain, diagnosis DB ketika masuk ke rumah sakit, lama demam sebelum masuk rumah sakit, denyut nadi per menit, tingkat pernafasan, kadar White Blood Cells, dan kadar platelets atau trombosit.

2) Faktor yang Signifikan Mempengaruhi Laju Kesembuhan Pasien DBD dengan Distribusi Generalized Gamma

Faktor-faktor yang dianggap signifikan untuk mempengaruhi laju kesembuhan pasien DBD di RSUD Dr. Soetomo jika diduga bahwa lama rawat inap pasien mengikuti pola distribusi Generalized Gamma adalah variabel jenis kelamin, pendidikan terakhir untuk kategori S1, pekerjaan untuk kategori pegawai negeri, pegawai swasta, dan lain-lain, fase DBD, lama demam sebelum masuk rumah sakit, fase DBD yang didiagnosis II, denyut nadi per menit, tingkat pernafasan, kadar white blood cells, dan kadat platelets atau trombosit.

\section{E. Laju Kesembuhan Pasien DBD}

Hazard rate (laju kesembuhan) pasien DBD RSUD Dr. Soetomo di masing-masing kecamatan yang berada di daerah Surabaya Timur dapat dimodelkan sebagai berikut. Model Laju Kesembuhan Pasien Distribusi Weibull

$$
\begin{gathered}
h(t)=2,368 t^{1,368} \exp \left(-3,898+0,6833 X_{1(\text { perempuan })}\right. \\
+0,3896 X_{3(S 1 / D 3)}
\end{gathered}
$$

$$
\begin{gathered}
-0,5509 X_{4(P . \text { Negeri })}+0,4727 X_{4 l a i n-l a i n}-0,4902 X_{5(I)} \\
-0,462 X_{6} \\
+0,74 X_{7}-0,5048 X_{8}-0,6802 X_{12}+0,7391 X_{13}
\end{gathered}
$$

Model Laju Kesembuhan Pasien Distribusi Generalized Gamma

$$
\begin{gathered}
h(t)=h_{0}(t) \exp \left(-2,154+0,7327 X_{1(\text { perempuan })}\right. \\
\left.+0,3812 X_{3(S 1 / D 3)}-0,4973 X_{4(P . N e g e r i}\right) \\
-0,5489 X_{4(P . S w a s t a)}+0,5492 X_{4 l a i n-l a i n}-0,4938 X_{5(I)} \\
-0,49 X_{6}+0,7913 X_{7} \\
-0,5521 X_{8}-0,626 X_{12}+0,6793 X_{13}
\end{gathered}
$$

\section{F. Perbandingan Model Survival}

WAIC merupakan bentuk Generalized nilai Akaike Information Criterion (AIC) ke dalam bentuk model statistika yang singular. Model terbaik yang dipilih adalah model yang memiliki nilai WAIC yang lebih kecil. Berikut ini pada Tabel 4 merupakan nilai WAIC dari masing-masing model survival. Berdasarkan Tabel 4 maka model yang dipilih adalah model survival dengan distribusi Weibull. Pemilihan ini dikarenakan nilai WAIC dari model tersebut sebesar 93,01 yang merupakan nilai WAIC terkecil dari model yang ada. Oleh sebab itu maka laju kesembuhan pasien DBD di Surabaya Timur dapat dimodelkan dengan model sebagai berikut.

$$
\begin{gathered}
h(t)=2,368 t^{1,368} \exp (-3,898 \\
+0,6833 X_{1(\text { perempuan })} \\
+0,3896 X_{3(S 1 / D 3)} \\
-0,5509 X_{4(\text { P.Negeri })}+0,4727 X_{4 \text { lain-lain }} \\
-0,4902 X_{5(I)}-0,462 X_{6} \\
+0,74 X_{7}-0,5048 X_{8}-0,6802 X_{12}+0,7391 X_{13}
\end{gathered}
$$

\section{KESIMPULAN DAN SARAN}

Kesimpulan yang diperleh dari hasil analisis yang telah dilakukan adalah sebagai berikut; (1)Distribusi dari lama rawat inap pasien DBD mengikuti pola ditribusi Generalized Gamma atau Weibull; (2)Pada penelitian model yang dipilih untuk memodelkan laju kesembuhan pasien DBD adalah model survival dengan distribusi Weibull. Faktor-faktor yang mempengaruhi laju kesembuhan pasien adalah variabel jenis kelamin, pendidikan terakhir pasien untuk kategori S1/D3, pekerjaan pasien untuk kategori pegawai negeri dan lain-lain, diagnosis DB ketika masuk ke rumah sakit, lama demam sebelum masuk rumah sakit, denyut nadi per menit, tingkat pernafasan, kadar White Blood Cells, dan kadar platelets atau trombosit.

Berdasarkan kesimpulan yang diperoleh, dapat dirumuskan saran sebagai berikut.(1)Untuk memodelkan dapat dipertimbangkan untuk kasus mixture pada data sehingga dapat menghasilkan hasil yang lebih baik; (2)Dapat dipertimbangkan untuk menambahkan efek spasial untuk penelitian selanjutnya; (3)Untuk pemerintah Kota Surabaya dapat mempertimbangkan untuk pencegahan penyakit DBD di beberapa kecamatan yang ada di Kota Surabaya. 


\section{DAFTAR PUSTAKA}

[1] W. H. O. WHO, "Dengue increase likely during rainy season: WHO warns," World Health Organization (WHO), 2019. https://www.who.int/westernpacific/news/detail/11-06-2019-dengueincrease-likely-during-rainy-season-who-warns.

[2] K. R. I. Ditjen P2P, "Situasi Penyakit Demam Berdarah di Indonesia Tahun 2017," 2018.

[3] S. Siegel and J. J. N. Castellan, "Nonparametric Statistics for the Behavioral Sciences," New York, Springer-Verlag, 1988.

[4] D. G. Kleinbaum and M. Klein, "Survival Analysis: A self-learning text, 2005," New York, Springer-Verlag, 2011.

[5] P. M. Grambsch and T. M. Therneau, "Proportional hazards tests and diagnostics based on weighted residuals," Biometrika, vol. 81, no. 3, pp.
515-526, 1994, doi: 10.1093/biomet/81.3.515.

[6] N. Iriawan, "Studi tentang 'Bayesian Mixture Normal'dengan menggunakan metode Markov Chain Monte Carlo (MCMC)," Lap. Penelit., 2001.

[7] W. M. Boldstat, Introduction to Bayesian Statistics, 2nd ed. New Jersey: John Wiley \& Sons. Inc, 2007.

[8] G. E. P. Box and G. C. Tiao, "Bayesian Inference in Statistical Analysis, Addision-Wesley," Reading, MA, 1973.

[9] W. R. Gilks and P. Wild, "Adaptive Rejection Sampling for Gibbs Sampling," Appl. Stat., vol. 41, no. 2, p. 337, 1992, doi: $10.2307 / 2347565$.

[10] A. Gelman, J. Hwang, and A. Vehtari, "Understanding predictive information criteria for Bayesian models," Stat. Comput., vol. 24, no. 6, pp. 997-1016, 2014. 